\title{
ТЕОРЕТИЧНІ ПІДХОДИ ДО РОЗУМІННЯ ЗАОЧНОЇ КРИМІНАЛЬНОЇ ПРОЦЕСУАЛЬНОЇ ФОРМИ
}

Маленко О. В.

У статті досліджується проблематика процесуально-правової природи заочної кримінальної процесуальної форми. На основі аналізу наведених доктринальних міркувань визначено наявні теоретичні підходи до розуміння відповідних питань та охарактеризовано кожен з них, обгрунтовано розкрито позитивні й негативні аспекти таких наукових концепцій та запропоновано авторське бачення заочного провадження як диференційованої форми кримінального провадження.

Ключові слова: кримінальний процес, кримінальна процесуальна форма, заочна кримінальна процесуальна форма.

В статье исследуется проблематика процессуально-правовой природы заочной уголовной процессуальной формы. На основе анализа приведенных доктринальных соображений определены имеющиеся теоретические подходы к понима нию соответствующих вопросов и охарактеризованы каждый из них, обоснованно раскрыто положительные и отрицательные аспекты таких научных концепций и предложено авторское видение заочного производства как дифференцированной формы уголовного судопроизводства.

Ключевые слова: уголовный процесс, уголовная процессуальная форма, заочная уголовная процессуальная форма.

This scientific article is devoted to one of the most controversial problems of the modern criminal process in Ukraine - the possibility of using a form of criminal proceedings in absentia.

The urgency of the study is due to the fact that for a long time the Criminal Procedure Code of Ukraine did not contain norms regulating the issue of criminal liability of a person who is being hid from the organs of pre-trial investigation and/or court, which led to the impossibility of performing the tasks entrusted to criminal proceedings in full measure. Subsequently, a criminal procedural institute for special criminal proceedings (special pre-trial investigation and special judicial proceedings) was introduced into the criminal process of Ukraine, which increased the scientific and practical interest in the problem of using a form of criminal proceedings in absentia.

Today in the scientific legal literature there are different approaches to understanding the legal nature of proceedings in absentia and its place and role in the criminal proceeding system of Ukraine, however, complexly relevant issues in the science of the criminal process have not been investigated. In this scientific article we, on the basis of the analysis of theoretical considerations given by domestic and foreign scientists, determined the existing theoretical approaches to understanding the relevant issues and characterized each of them, reasonably revealed the positive and negative aspects of such scientific concepts and suggested the author's vision of the legal nature of proceedings in absentia as a differentiated forms of criminal proceedings. It was concluded that criminal proceedings in absentia are special criminal procedural forms characterized by a combination of elements of simplification and complications of the criminal procedural form and simultaneous application of compensatory mechanisms that are intended to compensate by means determined by the Criminal Procedure Code of Ukraine, the actual absence of a suspect at the stage of pre-trial investigation and/or accused at the trial stage.

Key words: criminal procedure, criminal procedural form, criminal proceedings in absentia.
Постановка проблеми та їі актуальність. Розуміння кримінальної процесуальної форми $є$ одним 3 найбільш проблемних у теорії кримінального процесу, тому серед вчених відсутні єдині погляди стосовно визначення іiі правової природи, що зумовлює й плюралізм думок щодо сутності заочної кримінальної процесуальної форми, їі місця та ролі у кримінальному процесі. Проблематиці заочного провадження вітчизняні науковці приділяли недостатньо уваги, однак «тимчасове» закріплення відповідного інституту в КПК України в 2014 р. та внесення до КПК України змін щодо запровадження спеціального кримінального провадження, пожвавили наукові дискусії з цього питання, що обумовлює необхідність перегляду та переосмислення багатьох підходів до розуміння названої кримінальної процесуальної форми.

Аналіз останніх досліджень і публікацій. Окремі аспекти проблем заочного кримінального провадження висвітлювалися в працях таких учених, як: Г.П. Власова, І.В. Гловюк, І.М. Канюка, М.П. Климчук, Г.В. Матвієвська, О.О. Нагорнюк-Данилюк, І.В. Озерський, Р.Г. Пєсцов, І.І. Сливич, В.М. Трофименко, Л.Д. Удалова, О.Г. Яновська та інших. Разом з тим, комплексно відповідні питання не розглядалися в сучасній науковій юридичній літературі.

Метою статті $\epsilon$ теоретичний аналіз основних доктринальних підходів до розуміння правової природи заочної кримінальної процесуальної форми.

Виклад основного матеріалу. 3 вивчення вітчизняних та зарубіжних наукових джерел вбачаються такі основні концепції розуміння заочної кримінальної процесуальної форми:

1. Заочне провадження як спрощена кримінальна процесуальна форма.

Відсутність єдності вчених щодо категорії «спрощене кримінальне провадження» істотним чином впливає на вирішення питання про співвідношення заочного і спрощеного провадження. Т.Д. Дудоров вважає, що спрощене провадження представляє собою визначений законодавцем порядок здійснення окремих категорій кримінальних проваджень, що полягає у вилученні або скороченні процесуальних стадій, інститутів і норм при реалізації базових принципів судочинства та забезпечення гарантій прав і законних інтересів його учасників $[1$, с. 107]. Аналогічної позиції дотримується і Г.В. Матвієвська [2, с. 349]. Тобто спрощене провадження відрізняється від загального порядку здійснення провадження істотним спрощенням у застосуванні кримінальних процесуальних категорій, визначених КПК України.

На думку І. Морозової, спрощене судочинство являє собою законодавчо встановлену процедуру розгляду кримінальних проваджень, якій притаманні скорочені строки, відсутність окремих стадій та скасування деяких процесуальних інститутів і норм з метою забезпе- 
чення оптимальних шляхів досягнення завдань кримінального процесу [3, с. 37]. Отже, спрощення полягає не тільки у відмові від застосування певних кримінальних процесуальних категорій, але й у встановлені більш коротких строків вчинення процесуальних дій та прийняття процесуальних рішень, порівняно із загальним порядком. Крім того, його здійснення має на меті виконання всього комплексу завдань кримінального провадження, а не тільки забезпечення дотримання процесуальних гарантій та засад кримінального провадження.

Т.В. Трубнікова під спрощеним кримінальним судочинством розуміє провадження за окремими категоріями проваджень, які мають такі особливості, які об'єктивно потребують швидкого здійснення кримінальної процесуальної діяльності і простоти кримінальної процесуальної форми, яке здійснюється в більшості випадків з меншими затратами, чим провадження, яке здійснюється у загальному порядку [4, с. 85]. Таким чином, можливе застосування спрощеної процесуальної форми щодо певної категорії проваджень, яке повинно мати вужчу поширеність, ніж загальне кримінальне провадження. Скорочене провадження характеризується оперативністю здійснення процесуальної діяльності, простотою процесуальної форми та значно меншим розміром витрат на здійснення кримінального судочинства. Отже, Т.В. Трубнікова зводить сутність спрощеної процесуальної форми до засади процесуальної економії у кримінальному правосудді. Недоліком такого бачення $\epsilon$ те, що не розкривається зміст даної категорії, які фактори зумовлюють потребу відступити від загального порядку здійснення кримінального провадження тощо.

О.О. Нагорнюк-Данилюк вважає, що спрощене провадження не $є$ самостійним, а являє собою лише виняток із загального порядку, що обумовлено необхідністю здійснення кримінального провадження з найбільшою швидкістю, простотою та ефективністю [5, с. 117]. Наведені міркування суперечать теорії диференціації кримінальної процесуальної форми, оскільки в такому випадку повинна існувати тільки одна загальна процесуальна форма, а всі інші не мають самостійного значення та $\epsilon$ похідними від неї винятками. Разом з тим, вивчення i наукових джерел, i нормативно-правової бази свідчить про наявність істотних відмінностей між загальною та диференційованими формами кримінального провадження.

На думку І.І. Сливича, спрощена форма - це процесуальна форма провадження у кримінальному процесі України, яка має власну сукупність специфічних цілей i завдань, що не суперечать цілям і завданням кримінального судочинства в цілому, характеризується вилученням окремих стадій провадження, завдяки чому воно здійснюється у більш короткі строки [6, с. 100]. Тобто відмінною ознакою відповідного провадження $\epsilon$ спрощення процесуальної форми, яке досягається завдяки відмові від застосування окремих процесуальних стадій, інститутів та норм й скорочення процесуальних строків вчинення процесуальних дій та прийняття процесуальних рішень, але за умови дотримання основних принципів кримінального процесу.

На переконання Г.П. Власової, спрощене кримінальне провадження - це самостійне провадження, що має на меті швидке та повне забезпечення конституційних прав громадян, об'єктивно потребує по визначеній категорії проваджень більш ефективного та більш економного судового розгляду, в порівнянні з загальним порядком розгляду кримінального провадження, при суттєвій зміні кримінальної процесуальної форми на діючих принципах кримінального процесу, на яких базується кримінальний процесуальний закон [7, с. 514]. 3 наведеного можна визначити такі ознаки відповідної категорії: $\epsilon$ самостійною диференційованою процесуальною формою у системі кримінального провадження; характеризується істотною відмінністю від загальної форми здійснення кримінального провадження; відповідає загальним засадам кримінального судочинства; зумовлена об'єктивною потребою більш швидкого та економного розгляду певної категорії проваджень; застосовується на стадії судового провадження; має на меті швидке та повне забезпечення конституційних прав громадян.

Проте запропонований підхід потребує уточнення: 1) спрощене провадження може мати місце не тільки на стадії судового провадження, але й під час здійснення досудового розслідування; 2) метою застосування спрощеного провадження $\epsilon$ виконання завдань кримінального провадження, визначених кримінальним процесуальним законом, що, серед іншого, передбачає й забезпечення конституційних прав громадян.

Прибічником розуміння заочної процесуальної форми як спрощеного провадження $\epsilon$ В.Т. Маляренко, який свого часу звертав увагу на те, що заочне провадження і заочний вирок у кримінальних провадженнях, хоча й не $\epsilon$ новим процесуальним інститутом спрощеного провадження, проте недостатньо досліджений і відносно рідко застосовуваний у практиці через відсутність правового механізму [8, с. 7]. Однак науковець не наводить будь-яких аргументів з метою обґрунтування твердження щодо належності заочної кримінальної процесуальної форми саме до спрощеного провадження.

O.І. Назарук та Р.Л. Кислюк переконані, що інститут заочного кримінального провадження слід розглядати як спрощене провадження, оскільки він не має ознак для виділення його в самостійне провадження й не містить посилених процесуальних гарантій. Заочне провадження, на їх думку, - це свого роду виняток із загального правила, спрямований на швидке та ефективне здійснення кримінального провадження [9, с. 145]. Така позиція не виглядає переконливою, адже в доктрині обґрунтовуються позиції щодо розуміння заочної процесуальної форми і як самостійного провадження, і як провадження 3 посиленими процесуальними гарантіями, і як інші види кримінального провадження. За таких обставин віднесення досліджуваної категорії до числа спрощеного провадження потребує належного теоретичного аргументування. Окрім того, вказівка на швидкість та оперативність здійснення заочного провадження $\epsilon$ неповною, адже метою застосування відповідної процесуальної форми $\epsilon$ забезпечення принципу невідворотності кримінальної відповідальності, беззастережний захист прав та законних інтересів осіб, які потерпіли в результаті вчинення кримінальних правопорушень, захист інтересів держави у сфері правосуддя тощо.

Дослідник відповідних питань - І.М. Канюка, наголошує на тому, що з метою процесуальної економії доцільним $є$ запровадження в кримінальному судочинстві ще одного диференційованого виду кримінального провадження - заочного провадження, у порядку якого розглядалися б провадження про кримінальні пра- 
вопорушення осіб, що ухиляються від явки до суду. При цьому умовою постановлення заочного вироку, на думку І.М. Канюки, повинно бути перебування особи у розшуку не менше, ніж шість місяців, вжиття всіх заходів до повідомлення особи про висунуті щодо неї обвинувачення, а обвинувачений повинен мати право оскаржити заочний вирок в особливому порядку - до того ж суду, який його постановив, що матиме наслідком перегляд вироку у повному обсязі в загальному порядку [10, с. 16]. Заочне провадження розглядається як спосіб підвищення економічності кримінального процесу за допомогою диференціації кримінальної процесуальної форми. Заочне провадження у кримінальному процесі - це вид спрощеного провадження, при якому кримінальне провадження розглядається, а вирок ухвалюється за відсутності обвинуваченого [11, с. 195]. 3 авторського бачення сутності заочної кримінальної процесуальної форми слідує, що вона має спрощений характер порівняно з загальною кримінальною процесуально формою, що здійснюється з метою досягнення процесуальної економії у кримінальному провадженні. Такі міркування видаються достатньо дискусійними, адже заочне кримінальне провадження не має на меті досягнення швидкого винесення вироку, зекономити матеріальні або часові ресурси держави або учасників кримінального провадження тощо, навпаки, як свідчить практика застосування даного кримінального процесуального інституту, і часові, і матеріальні витрати в більшості випадків значно перевищують обсяги, що мають місце при здійсненні загальних кримінальних процесуальних процедур.

О.В. Сачков вважає, що особливі форми, порядки та режими кримінальних проваджень, які викладені в КПК України, умовно можна розділити на дві групи: спрощені форми кримінального провадження та ускладнені форми кримінального провадження. До першої належить: провадження на підставі угод; здійснення спеціального (заочного) досудового розслідування; особливий режим досудового розслідування в умовах воєнного, надзвичайного стану або у районі проведення АТО; кримінальне провадження у формі приватного обвинувачення; провадження щодо кримінальних проступків [12, с. 133]. Такий підхід носить поверхневий характер, оскільки: 1) відсутній класифікаційний критерій, який дозволяє провести таку чітку межу між відповідними формами; 2) аналіз запропонованих спрощених форм кримінального провадження свідчить, що вони $\epsilon$ неоднорідними й мають істотні відмінності в моделі кримінального провадження, а тому й не можуть бути об'єднані в межах однієї групи диференціації кримінальної процесуальної форми.

Прибічником розуміння відповідного виду кримінального провадження як спрощеної процесуальної форми $є$ 0.0. Нагорнюк-Данилюк, який вважає, що інститут спеціального кримінального провадження необхідно розглядати як спрощену форму кримінального провадження, яка охоплює спеціальне досудове розслідування і спеціальне судове провадження та передбачає особливий порядок їх здійснення, щодо злочинів, виключний перелік яких визначений у кримінальному процесуальному законі, стосовно підозрюваного чи обвинуваченого, який перебуває за межами України, ухиляється від явки на виклик слідчого, прокурора, слідчого судді, суду та оголошений у міждержавний та/або міжнародний розшук, з метою забезпечення швидкого та ефективного захисту особи, суспільства та держави від кримінальних правопорушень [5, с. 118]. 3 аналізу даної дефініції можна встановити такі ознаки цього інституту: 1) діє щодо обмеженого кола злочинів; 2) має місце на стадії досудового розслідування та судового провадження; 3) здійснюється в особливому порядку; 4) підставами його застосування $\epsilon$ ухилення підозрюваного (обвинуваченого) від явки на виклик слідчого, прокурора, слідчого судді, суду та оголошення у міждержавний та/або міжнародний розшук; 5) метою $\epsilon$ забезпечення швидкого та ефективного захисту особи, суспільства та держави від кримінальних правопорушень.

Заслуговують на увагу міркування І.В. Гловюк, що кримінальне провадження in abstentia має такі важливі ознаки спрощеного провадження: не проводяться деякі слідчі (розшукові), судові та інші процесуальні дії у зв'язку з фактичною відсутністю підозрюваного, обвинуваченого (вручення повідомлення про підозру, допит підозрюваного, відкриття матеріалів досудового розслідування підозрюваному, встановлення особи обвинуваченого, роз'яснення його прав, допит обвинуваченого, його участь в судових дебатах, останнє слово обвинуваченого) [13, с. 18]. Дійсно, аналіз КПК України свідчить, що фізична відсутність підозрюваного під час здійснення спеціального досудового розслідування та обвинуваченого під час спеціального судового провадження, має наслідком неможливість вчинення певних слідчих (розшукових) та процесуальних дій, однак наведене не свідчить про істотне спрощення кримінальної процесуально форми, оскільки: 1) підозрюваний (обвинувачений) в будь-який час може з' явитися до органів досудового розслідування чи суду в результаті чого матиме місце припинення процедури здійснення заочного кримінального провадження та перехід до загальної кримінальної процесуальної форми; 2) поряд із спрощенням кримінальної процесуальної форми, має місце іï ускладнення в результаті чого виникає необхідність залучення додаткових суб'єктів до здійснення кримінального провадження, підготовки окремих процесуальних рішень, вчинення додаткових процесуальних дій тощо, що свідчить про відсутність як скорочених процесуальних строків, так й істотного спрощення стадій, інститутів, норм, в результаті чого не відбувається зменшення процесуальних витрат тощо.

Беручи до уваги наведене, відсутні підстави для віднесення заочного кримінального провадження до спрощеної кримінальної процесуальної форми, однак складність та багатоманітність досліджуваної категорії, а також аналіз її процесуально-правової природи, дає підстави однозначно стверджувати про наявність у межах заочного кримінального провадження окремих елементів спрощення кримінальної процесуальної форми, але їх обсяг не $\epsilon$ настільки суттєвим, щоб вести мову про істотну спрощеність такої процесуальної форми.

2. Заочне провадження як целерантна кримінальна процесуальна форма.

Найменування відповідної правової категорії походить від латинського слова celerantes - швидкий, стрімкий, прискорений тощо [6, с. 97]. В науковій літературі 3 проблематики кримінального судочинства відсутні єдині підходи до розуміння сутності відповідної кримінальної процесуальної форми. 
Російські вчені О.В. Смірнов та К.Б. Калиновський зазначають, що в загальнотеоретичному плані прискорене та спрощене провадження - це такі форми кримінального процесу, які призначені для вирішення кримінальних проваджень у скорочені строки та за спрощеними правилами [14, с. 220]. Тобто спрощене та прискорене провадження $\epsilon$ єдиною формою здійснення кримінального провадження, які $\epsilon$ невіддільними й функціонують у своїй єдності («широке» розуміння целерантного кримінального провадження).

Водночас наявні й інші наукові позиції, які можна охарактеризувати як «вузьке» розуміння целерантної форми. На переконання О.В. Волколуп, для целерантної процесуальної форми визначне значення має категорія «угода» [15, с. 231]. За таких умов поняття «провадження на підставі угод» та «целерантне провадження» $\epsilon$ тотожними, що виключає можливість розуміння заочного кримінального судочинства крізь призму целерантного провадження.

Іншої думки притримується І.І. Сливич, вказуючи, що стосовно спрощених і прискорених процедур судочинства застосовуються два терміни: целеранте та сумарне судочинство, які не $\epsilon$ тотожними категоріями та мають відмінності [6, с. 98]. Прискорена форма провадження у кримінальному процесі України спрямована на досягнення загальних цілей кримінального судочинства, яке має скорочені (порівняно зі звичайною процедурою) строки для їх досягнення і особливості, які характеризуються модифікацією окремих стадій кримінального провадження, що відрізняє ці провадження від звичайного порядку кримінального судочинства [6, с. 100]. 3 наведених міркувань вбачається, що головними ознаками відповідної форми кримінального провадження $\epsilon$ :

1) скорочені строки здійснення процесуальних дій та прийняття процесуальних рішень. Вказана ознака $\epsilon$ визначальною для спрощеного кримінального провадження, яке передбачає спрощення і шляхом встановлення менших процесуальних строків для вчинення процесуальних дій та прийняття процесуальних рішень, так і шляхом відмови від застосування або обмеженого застосування процесуальних інститутів, стадій кримінального провадження тощо. За таких обставин навряд чи скорочені процесуальні строки можна визначити як притаманну рису целерантного (прискореного) провадження.

Варто звернути увагу на окремі підходи до розуміння процесуально-правової природи спрощеного та целерантного кримінального судочинства. Так, деякі вчені вважають, що в межах целерантної кримінальної процесуальної форми слід виділяти ії підвиди, а саме: 1) процесуальні форми, засновані на засаді доцільності здійснення кримінального переслідування, що полягає в тому, що під час здійснення кримінального провадження можуть виникнути підстави для відмови від підтримання обвинувачення стороною обвинувачення, що матиме наслідком, за певних обставин, закриття кримінального провадження; 2) сумарне провадження (від лат. summarium - стислий виклад), що опосередковує різноманітні кримінальні процесуальні форми щодо розгляду кримінальних проваджень незначної складності, без проведення досудового розслідування, коли не здійснюється дослідження наявних доказів тощо; 3) угоди у кримінальному провадженні [14, с. 221]. Таким чином, якщо целерантне провадження розгля- дати у «широкому» значенні, одним з його різновидів $\epsilon$ спрощена кримінальна процесуальна форма (охоплюється поняттям «сумарне провадження»). Саме за таких обставин скорочені процесуальні строки можуть бути характерною рисою целерантного провадження, однак така риса не може характеризувати целерантне провадження як самостійну процесуальну форму, оскільки в іншому разі вона буде тотожна поняттю спрощеного провадження.

2) щодо модифікації стадій кримінального провадження, то характерною рисою спрощеної процесуальної форми $\epsilon$ саме така зміна стадій кримінального процесу, яка має істотний характер і дозволяє відмежувати спрощене провадження від загального порядку здійснення кримінального судочинства. Визначальне значення має саме спрощення, тобто відмова від застосування або обмежений характер застосування стадій кримінального провадження. Однак за таких умов целерантне провадження буде мати тотожний зміст зі спрощеною процесуальною формою.

Якщо вести мову про таку модифікацію стадій кримінального провадження, яка ускладнює здійснення кримінального судочинства, порівняно $з$ загальним порядком, то це буде суперечити самій ідеї целерантної кримінальної процесуальної форми. В науковій юридичній літературі зазначається, що до завдань даного виду кримінального провадження належить: 1) процесуальна економія (скорочення часу, сил і засобів, що використовуються для вирішення частини кримінальних проваджень і вивільнення їх для провадження у найбільш складних кримінальних провадженнях); 2) наближення моменту покарання винуватого до вчинення злочину з метою посилення попереджувального впливу процедур судочинства та кримінального покарання; 3) примирення сторін [14, с. 220]. Отже, целерантна модель передбачає спрощення процесуальної форми, що виключає модифікацію кримінального провадження у напрямі ії обтяження та ускладнення.

Прихильником розуміння заочного кримінального судочинства як целерантної процесуальної форми $\epsilon$ I.В. Озерський, який вважає, що впровадження у кримінальний процес України інституту заочного провадження можна вважати одним із способів прискорення досудового розслідування за відсутності підозрюваного (обвинуваченого) [16, с. 114]. Слід зазначити, що целерантне провадження може мати місце не тільки під час досудового розслідування, але й під час судового провадження.

І.І. Сливич вважає, що прискорена форма кримінального провадження спрямована на досягнення спільних цілей кримінального судочинства. Це форма, що має скорочені (у порівнянні зі звичайною процедурою) строки для їх досягнення завдяки тому, що окремі її стадії модифікуються у зв'язку зі специфікою провадження. Як приклад прискореної процедури можна привести спеціальне провадження у кримінальному судочинстві України, коли зміст та форма кримінального провадження за відсутності підозрюваного або обвинуваченого повинні відповідати загальним засадам кримінального провадження. Об'єктивні потреби сьогодення, а саме реалізація завдань кримінального провадження по відношенню до осіб, які переховуються за кордоном, в окупованій АРК, на територіях Донецької та Луганської областей, що тимчасово не підконтрольні 
українській владі, викликали необхідність появи нової процесуальної форми, якою $є$ спеціальне провадження [6, с. 99]. Наведені твердження не можуть свідчити про те, що заочна процесуальна форма належить до целерантних форм кримінального судочинства, оскільки за темпоральними характеристиками вона не поступається загальному порядку здійснення кримінального провадження, окрім того, досудове розслідування та судовий розгляд $є$ навіть більш ускладненими, ніж загальна процедура.

3. Заочне провадження як кримінальна процесуальна форма з посиленими процесуальними гарантіями.

Х.У. Рустамов вважає, що заочна модель судочинства належить до кримінальної процесуальної форми з посиленими процесуальними гарантіями нарівні з розглядом провадження судом присяжних, провадження щодо неповнолітніх, провадження щодо осіб, які мають психічні чи фізичні вади тощо [17, с. 312]. Процесуальними гарантіями можуть бути: наявність письмової згоди обвинуваченого на розгляд кримінального провадження без його участі; належне повідомлення обвинуваченого про місце та час судового розгляду; нездійснення правосуддя щодо осіб, які мають фізичні чи психічні вади, не володіють мовою провадження, неповнолітніх тощо [18, с. 290]. Для даного підходу є характерним застосування додаткових кримінальних процесуальних заходів, порівняно із загальним порядком, що й відрізняє заочне провадження серед кримінальних процесуальних форм на рівні з деякими іншими диференційованими формами кримінального провадження.

А.С. Тукієв заочне кримінальне провадження визначає як особливий порядок досудового розслідування і судового розгляду кримінальних проваджень, який допускається за наявності визначених в законі підстав та умов, базується на дослідженні загального предмета доказування й інших обставин провадження, що здійснюється за відсутності підозрюваного (обвинуваченого), якому належить право, крім загальних, на особливий порядок оскарження заочного вироку. Науковець пропонує за критерієм відмінностей рівня процесуальних гарантій, які відрізняються від загального порядку кримінального провадження, виділяти кримінальні провадження з посиленими процесуальними гарантіями прав та законних інтересів осіб щодо яких здійснюється кримінальне провадження, до числа яких, серед інших, належить заочне кримінальне провадження. Заочне кримінальне судочинство не надає ні суду, ні сторонам захисту чи обвинувачення додаткових прав і гарантій крім тих, які вони мають при звичайному провадженні. Закон лише повинен наділяти сторону захисту додатковими гарантіями ніби «на противагу» відсутності підозрюваного (обвинуваченого) і можливим внаслідок цього процесуальним наслідкам [19, с. 11]. Відповідні «додаткові гарантії» стосуються не сторони захисту в цілому, а саме підозрюваного (обвинуваченого) щодо якого здійснюється провадження і лише під час застосування такої кримінальної процесуальної форми.

На переконання О.В. Трофімової, інститут заочного кримінального судового розгляду це вид особливого порядку судового розгляду з посиленими процесуальними гарантіями, при якому даний розгляд відбувається за відсутності обвинуваченого у зв'язку з неможливістю реалізації призначення кримінального судочинства у звичайному порядку і наявністю виняткових причин, пов'язаних із забезпеченням особливо важливих інтересів держави, суспільства та особистості, а також наявністю умов, передбачених кримінальним процесуальним законом [20, с. 320]. У відповідній кримінальній процесуальній формі передбачені додаткові процесуальні гарантії, порівняно із загальними правилами здійснення кримінального провадження, застосування яких обумовлено фактичною відсутністю обвинуваченого на стадії судового розгляду кримінального провадження.

На думку І.В. Гловюк, заочне кримінальне судочинство не можна відносити до кримінальної процесуальної форми з посиленими процесуальними гарантіями, оскільки характер наданих гарантій має швидше за все не додатковий (підсилюючий), а заміщуючий характер, спрямований на усунення тих загроз застосуванню щодо підозрюваного, обвинуваченого належної правової процедури, що можуть мати місце при їх фактичній відсутності протягом досудового розслідування та судового розгляду [13, с. 18-19]. Заслуговують на увагу й міркування О.О. Нагорнюка-Данилюка, що спеціальне кримінальне провадження не можна розглядати як кримінальне провадження з посиленими процесуальними гарантіями, оскільки воно здійснюється за відсутності підозрюваного або обвинуваченого і зумовлює зміни форм діяльності учасників кримінального процесу (відсутність допиту обвинуваченого, оголошення його показань, особливості оскарження заочного вироку тощо), що навряд чи може свідчити про підсилення процесуальних гарантій, а є доказом їх зниження [5, с. 117]. На наше переконання, заочне кримінальне провадження не можна відносити до кримінальної процесуальної форми з посиленими процесуальними гарантіями, оскільки вона не містить більш посилених (підвищених) процесуальних гарантій для учасників кримінального провадження, в тому числі й підозрюваного (обвинуваченого), порівняно з загальним порядком здійснення кримінального провадження.

Для досліджуваної кримінальної процесуальної форми характерним $\epsilon$ застосування інших правових явищ - компенсаторних кримінальних процесуальних механізмів, які покликані компенсувати відсутність підозрюваного під час здійснення досудового розслідування та обвинуваченого під час проведення судового розгляду кримінального провадження, й забезпечити можливість реалізації прав та законних інтересів такого учасника кримінального провадження, який фактично не бере в ньому участі, з метою виконання завдань кримінального провадження, визначених кримінальним процесуальним законом України.

4. Заочне провадження як особлива кримінальна процесуальна форма.

В доктринальних джерелах із проблематики кримінального процесу пропонується розуміння заочного кримінального провадження як особливої кримінальної процесуальної форми. Аналіз наукової літератури, в якій висвітлено питання кримінального процесуального права, свідчить про різне розуміння категорії «особливе» в даному випадку, однак найчастіше мова йде про те, що оскільки досліджуване правове явище характеризується спрощенням та ускладненням під час здійснення кримінального провадження, його не можна віднести до загального порядку проведення 
кримінального судочинства, а також чітко класифікувати за певною диференційованою процесуальною формою, то воно займає особливе місце в кримінальному провадженні.

К.Г. Бендерська, яка базує своє дослідження на положеннях російського кримінального процесуального закону, вказує, що при розгляді заочного кримінального провадження фактично йде мова про два різні види судочинства: 1) одне з них спрощує здійснення кримінального провадження, прискорюючи його (за ч. 4 ст. 247 КПК РФ); 2) інше навпаки, є провадженням 3 посиленими процесуальними гарантіями та уповільнює кримінальний процес через складності виконання вироку, неоднозначну практику порядку оскарження вироку тощо. Таким чином, заочне кримінальне провадження це особливий вид провадження за критерієм кола суб'єктів, а також за ознакою категорії провадження за якими можливе його застосування [21, с. 19]. Аналогічної позиції дотримується і О.О. Казаков, який вказує, що процедуру здійснення провадження за відсутності обвинуваченого слід розглядати як самостійну особливу процесуальну форму, яка займає окреме місце в системі кримінального провадження, оскільки їі неможливо віднести до провадження з посиленими процесуальними гарантіями, окрім того, за деякими винятками, не можна розглядати як і спрощену процесуальну форму [22, с. 159]. Отже, в кримінальному судочинстві мають місце різні форми: спрощене провадження, коли сам обвинувачений просить розглянути кримінальне провадження за його відсутності, та заочне провадження, коли обвинувачений свідомо ухиляється від здійснення кримінального провадження щодо нього за його безпосередньої участі.

Більш обґрунтованою видається позиція І.В. Гловюк, яка вказує, що у системі кримінальних процесуальних проваджень провадження in absentia займає окреме, особливе місце, оскільки містить елементи і спрощення, і ускладнення кримінальної процесуальної форми. Так, провадження in abstentia має такі ознаки спрощеного провадження: не проводяться деякі слідчі (розшукові), судові та інші процесуальні дії у зв'язку з фактичною відсутністю підозрюваного, обвинуваченого (вручення повідомлення про підозру, допит підозрюваного, відкриття матеріалів досудового розслідування підозрюваному, встановлення особи обвинуваченого, роз'яснення його прав, допит обвинуваченого, його участь в судових дебатах, останнє слово обвинуваченого). Про ускладненість цього провадження свідчать такі його ознаки як: обов' язкова участь захисника; здійснення досудового розслідування на підставі ухвали слідчого судді, а судового провадження - на підставі ували суду; особливий порядок виклику підозрюваного (обвинуваченого); під час здійснення спеціального судового провадження досліджуються всі надані докази; у вироку суд окремо обґрунтовує, чи були здійснені стороною обвинувачення всі можливі передбачені законом заходи щодо дотримання прав підозрюваного чи обвинуваченого на захист та доступ до правосуддя з урахуванням встановлених законом особливостей такого провадження [13, с. 18-19]. Отже, вченою розглянуто спрощення та ускладнення процесуальної форми в межах виключно заочного кримінального провадження без врахування суміжних правових категорій, зокрема спрощеного провадження щодо кримінальних проступків, яке за своєю правовою природою $є$ відмінним від заочного кримінального провадження правовим явищем.

Разом з тим, навряд чи особлива кримінальна процесуальна форма, яка характеризується поєднанням ознак спрощеного та ускладненого кримінального провадження, порівняно із загальним порядком здійснення кримінального провадження, може повним чином охарактеризувати сутність досліджуваної правової категорії. Наведене обґрунтовується тим, що поєднання спрощення й ускладнення характерне і для інших форм кримінального провадження. Зокрема, кримінальне провадження на підставі угод, з одного боку, передбачає можливість ухвалити вирок як на стадії досудового розслідування, так і під час судового розгляду, що істотним чином і прискорює, i спрощує процесуальну форму, з іншого боку, затвердження угоди вимагає потреби в їі розгляді судом, наявні спеціальні вимоги до змісту вироку, яким затверджується угода, згодом може мати місце скасування вироку, яким затверджена угода, судом, що його ухвалив та інше, що свідчить про ускладнення процесуальної форми, порівняно з загальним порядком.

Висновки. У доктрині кримінального процесу не вироблено теоретичної моделі такої кримінальної процесуальної форми, яка би в повній мірі відображала всі особливості здійснення заочного кримінального провадження. Ми вважаємо, що досліджувана категорія належить до особливої процесуальної форми, яка характеризується поєднанням спрощення та ускладнення кримінальної процесуальної форми з застосуванням компенсаторних механізмів, які покликані компенсувати (замінити) за допомогою процесуальних засобів, передбачених кримінальним процесуальним законом, фактичну відсутність підозрюваного (обвинуваченого) під час здійснення заочного провадження максимально можливими та ефективними способами для дотримання засад кримінального судочинства та виконання завдань кримінального провадження.

\section{Література}

1. Дудоров Т.Д. Дифференциация уголовно-процессуальной формы посредством упрощения порядка производства: история и современные тенденции. Вестник Краснодарского университета МВД России. 2009. № 1. C. 104-108.

2. Матвієвська Г.В. Заочне провадження як форма кримінального судочинства. Університетські наукові записки. 2011. № 3. С. 347-355.

3. Морозова И., Анненков А., Дадонов С. Сделка о признании вины как вариант мирового соглашения. Российская юстиция. 2000. № 10. С. 35-37.

4. Трубникова Т.В. Теоретические основы упрощенных судебных производств. Томск. 1999. 132 с.

5. Нагорнюк-Данилюк О.О. Поняття, сутність і значення інституту спеціального провадження в кримінальному процесі України. Право і Безпека. 2015. № 2. С. 113-120.

6. Сливич І.І. Прискорені та спрощені провадження в кримінальному судочинстві України: визначення та доцільність застосування. Науковий вісник Ужгородського національного університету: Серія: право. 2015. Вип. 31. Т. 3. С. $97-100$.

7. Власова Г.П. Сутність і завдання спрощеного кримінального судочинства. Актуальні проблеми держави $i$ права. 2011. Вип. 57. С. 511-516.

8. Маляренко В.Т. Про заочне провадження у кримінальному судочинстві. Право України. № 9. 2004. С. 3-12. 


\section{Організаційно-правові аспекти досудового слідства}

9. Назарук О.І., Кислюк Р.Л. Актуальні питання кримінального провадження in absentia. Правова держава. 2017. № 26. С. 144-148.

10. Канюка І.М. Принцип процесуальної економії в кримінальному судочинстві України: автореф. дис. ... канд. юрид. наук: 12.00.09. Одеса. 2015. 20 с.

11. Канюка І.М. Принцип процесуальної економії в кримінальному судочинстві України: дис. ... канд. юрид. наук: 12.00.09. Одеса. 2015. 257 с.

12. Сачко О.В. Забезпечення верховенства права під час застосування спрощених та інших особливих форм і режимів кримінального провадження. Актуальні проблеми вітчизняної юриспруденції. 2016. Вип. 6 (1). С. 133-136.

13. Гловюк І.В. Кримінальне провадження за відсутності підозрюваного або обвинуваченого (in absentia) у системі кримінального провадження України. Право України. 2015. № 7. С. 16-25.

14. Смирнов А.В., Калиновский К.Б. Уголовный процесс. Краткий курс. 2-е изд. СПб.: Питер. 2009. 304 с.

15. Волколуп О.В. Сокращение судебное разбирательство. Ученые записки. Коаснодар: Из-во Кубан. Ун-та. 2003. Вып. 2. С. 231-232.

16. Озерський І.В. Скасування заочного провадження в кримінальному процесі України як передумова суттєвого погіршення прав та законних інтересів потерпілої особи від правопорушення. Науковий вісник Ужгородського національного університету: Серія: Право. 2014. Вип. 24. T. 4. C. 111-115.

17. Рустамов Х.У. Дифференциация форм уголовного процесса (современные тенденции и проблемы совершенствования): дис. ... д-ра юрид. наук: 12.00.09. Москва. 1997. 339 C.

18. Рустамов Х.У. Уголовный процесс. Формы: учеб. пособие. Москва: Закон и право; Юнити. 1998. 304 с.

19. Тукиев А.С. Проблемы процессуальной формы заочного уголовного судопроизводства: автореф. дис. ... канд. юрид. наук: 12.00.09. Караганда. 2005. 30 с.

20. Трофимова Е.В. Заочное судебное разбирательство по уголовным делам: понятие и перспективы применения. Вестник Воронежского государственного универcumema. Серия «Право». 2008. № 2. С. 313-322.

21. Бендерская Е.Г. Рассмотрение уголовного дела в отсутствие подсудимого: автореф. дис. ... канд. юрид. наук: 12.00.09. Москва. 2010. 30 с.

22. Казаков А.А. Заочное судебное разбирательство уголовных дел: дис. ... канд. юрид. наук: 12.00.09. Екатеринбург. 2009. 280 с.

Маленко О. В., аспірант кафедри кримінального процесу та криміналістики Академії адвокатури України 